\title{
Perancangan Perangkat Antarmuka Berbasis Pengenalan Suara pada Purwarupa Mesin Cetak Huruf Braille ITS untuk Operator Tunanetra
}

\author{
Nicolas Rezadhi Pradipta, Tasripan, Hendra Kusuma \\ Departemen Teknik Elektro, Fakultas Teknologi Elektro, Institut Teknologi Sepuluh Nopember \\ e-mail: tasripan@ee.its.ac.id
}

\begin{abstract}
Abstrak - Pada pembuatan Purwarupa Mesin Cetak Huruf Braille ITS sejak tahun 2012 yang dikerjakan oleh Tim FTE ITS yang bekerjasama dengan Direktorat Pembinaan PK-LK Dikdas, Direktorat Jenderal Pendidikan Dasar, Kementrian Pendidikan dan Kebudayaan, sampai pada tahun 2017 sudah banyak mengalami perkembangan. Banyak nya perkembangan ini membuat purwarupa ini memiliki kelebihan dan banyak fitur. Salah satunya kemudahan dalam pengoperasian serta kompatibel dengan sistem operasi komputer modern. Dengan adanya sistem operasi komputer modern ini sangat memudahkan operator purwarupa Mesin Cetak Huruf Braille ITS. Tetapi sistem operasi ini masih memiliki kemelahan yaitu masih membutuhkan operartor non-tunanetra. Dengan adanya perangkat antarmuka berbasis suara yang terkoneksi pada sistem operasi, purwarupa ini dapat dioperasikan oleh operator penyandang tunanetra juga sehingga dapat lebih memudahkan pengoperasian purwarupa. Dirancang menggunakan Voice Recognition Module by Elechouse dan STM32F4 Discovery, sistem ini memasukkan database dari suara yang sudah dilatih berupa data hexadecimal kedalam STM32 yang lalu berkomunikasi dengan purwarupa. Dengan 4 perintah suara untuk mengoperasikan purwarupa ini, hasil yang didapat bekerja dengan rata-rata keberhasilan pengenalan suara sebesar $60,94 \%$ menggunakan referensi suara orang lain dan $\mathbf{7 7 , 9 2 \%}$ menggunakan referensi suara sendiri.
\end{abstract}

Kata Kunci- Kontrol Suara, Mesin Cetak Braille, Modul Pengenalan Suara, Perangkat Antarmuka

\section{PENDAHULUAN}

$S^{-1}$ EJAK tahun 2012 lalu ITS sedang menggarap riset purwarupa dari Mesin Cetak Huruf Braille. Purwarupa Mesin Cetak Huruf Braille ini merupakan pengembangan dari mesin cetak dari norwegia yang dimiliki SLB YPAB. Dengan bekerja sama dengan Direktorat Pembinaan PK-LK Dikdas, Direktorat Jenderal Pendidikan Dasar, dan Kementrian Pendidikan dan Kebudayaan, Tim dari FTE ITS membuat purwarupa dari Mesin Cetak Huruf Braille dengan hampir 85\% menggunakan suku cadang lokal buatan Indonesia. urwarupa yang dikembangkan oleh Tim FTE ITS ini memiliki kelebihan dan beberapa fitur antara lain adalah hemat energi, mudahnya pengoperasian dan pemeliharaannya, mampu mencetak karakter normal braille sebanyak 400 karakter/detik dengan maksimum 42 karakter/baris, dan dapat mencetak langsung pada 2 sisi kertas[1]. Purwarupa Mesin Cetak Huruf Braille ITS ini mempunyai manfaat yang besar bagi para penyandang tunanetra, terutama sebagai media untuk memudahkan pembelejaran pada Sekolah Luar Biasa yang ada di Indonesia.

Dalam pengoperasian sebuah alat diperlukan adanya sistem antarmuka (interface) yang dapat memudahkan interaksi antara manusia sebagai user dengan alat yang akan dioperasikan. Pengembangan-pengembangan mengenai bagaimana interaksi antara manusia dan mesin terus melaju pesat, sektor pengembangan ini lebih sering dikenal sebagai Human Machine Interface atau Human Machine Interaction atau Human Computer Interaction. Sejak awal penggarapan riset Purwarupa Mesin Cetak Huruf Braille ITS ini sudah terdapat banyak fitur-fitur yang dikembangkan untuk membuat purwarupa ini menjadi semakin sempurna, namun masih ada beberapa kelemahan yang sebenarnya dapat dikembangkan agar lebih memudahkan pengoperasiannya. Salah satu kelemahannya yaitu dalam hal pengoperasian. Walaupun sistem operasi nya sudah berbasis komputer modern, purwarupa Mesin Cetak Huruf Braille ITS ini masih membutuhkan operator yang bukan merupakan penyandang tunanetra. Jika operator nya juga merupakan penyandang tunanetra, maka harus adanya upaya dari mereka untuk menghafalkan dan juga membiasakan/latihan untuk mengoperasikan dengan jangka waktu yang cukup lama, untuk itu dalam memudahkan penyandang tunanetra untuk dapat mengoperasikan purwarupa Mesin Cetak Huruf Braille ITS ini dibutuhkan perangkat antarmuka yang dibuat khusus untuk penyandang tunanetra.

Dengan adanya perangkat antarmuka dengan basis pengenalan suara, ditambah lagi dengan fitur tombol yang bersuara para penyandang tunanetra dapat dengan mudah mengoperasikannya tanpa harus menghafal tombol operasi dari purwarupa mesin itu sendiri.

\section{METODE PENELITIAN}

\section{A. Produksi Sinyal Manusia Secara Fisiologis}

Suara adalah salah satu elemen yang berperan penting dalam kehidupan manusia karena suara adalah salah satu media manusia untuk berkomunikasi. Suara juga dapat menyatakan informasi pribadi seperti status sosial, kepribadian seseorang, dan juga kondisi emosional dari pembicaranya[2]. Suara merupakan alat utama dalam hal berkomunikasi baik antar manusia maupun manusia dengan mesin. Karena itu sebelum kita bisa meproses sinyal suara dalam bentuk sinyal digital, kita harus terlebih dahulu mengerti bagaimana proses sinyal suara terbentuk dari dalam tubuh manusia.

Secara fisiologis, suara manusia diproduksi melalui 3 proses utama yaitu proses pernafasan yang mana dikerjakan oleh paru-paru sebagai sumber energi. Proses kedua adalah proses pembunyian yang dikerjakan oleh laring. Setelah disalurkan dari paru-paru melalui trakea, energi berupa aliran udara akan sampai pada laring yang bekerja sebagai resonator. Proses pada laring yang paling utama adalah pita suara. Pita suara yang terbuka dan tertutup secara cepat membuat aliran udara dari trakea menjadi terhalang oleh pita 
suara dan membuat pita suara bergetar dan menghasilkan suara.

Kedua organ (baca: paru-paru dan laring) bersama menyesuaikan nada, kenyaringan, dan kualitas suara, dan selanjutnya menghasilkan pola prosodi suara[3]. Proses ketiga adalah artikulasi, suara yang dihasilkan oleh pita suara di modifikasi menjadi suara yang dapat dimengerti dan menghasilkan vokal dan konsonan. Artikulasi ini lah yang membuat adanya warna suara pada masing-masing manusia. Pada Gambar 1. dapat kita lihat terbaginya komponen fisiologis dari organ suara manusia yaitu, komponen subglotal, laring, dan komponen supraglotal (supralaryngeal). Ketiga komponen inilah yang membedakan tempat terjadinya 3 proses yang sudah dijelaskan diatas.

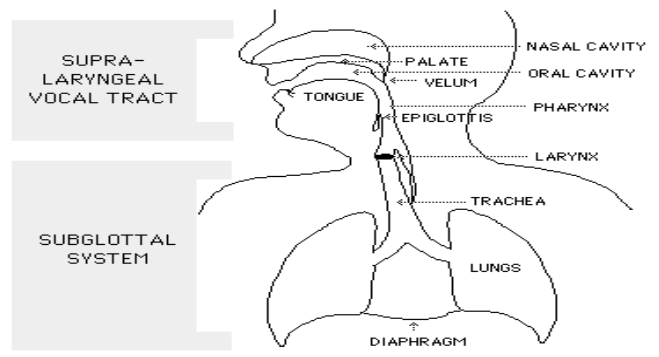

Gambar 1. Komponen fisiologis organ suara manusia[4].

\section{B. Pengenalan Suara}

Pengenalan suara merupakan salah satu metode dari Human-Machine Interaction yang dikembangkan agar manusia dapat mengoperasikan suatu mesin dengan menggunakan suara. Proses pengenalan suara dapat dibagi menjadi pengenalan pembicara dan pengenalan ucapan. Pada pengenalan pembicara (Speaker Recognition) pengidentifikasian suara nya berdasarkan suara orang yang berbicara sedangkan pada pengenalan ucapan (Speech Recognition) yang di identifikasi adalah suara berdasarkan kata yang diucapkan. Sistem pengenalan suara memiliki tujuan utama untuk mengerti lalu memberi aksi pada informasi suara yang diberikan[5].

Pada umumnya proses dari pengenalan suara dapat kita lihat pada Gambar 2. Dapat kita lihat pada Gambar 2. terdapat dua fase yaitu fase pelatihan dan fase pencobaan atau pengenalan. Pada fase pertama yaitu fase pelatihan, suara masuk kedalam sistem ekstraksi fitur dan disimpan dalam suatu perangkat. Suara-suara yang terkumpulkan dan disimpan dalam perangkat dianggap sebagai referensi.

Proses pelatihan ini biasanya dilakukan beberapa kali, karena merupakan proses neural network proses latihan ini jika dilakukan lebih banyak akan membuat suara yang akan dikenali lebih akurat.

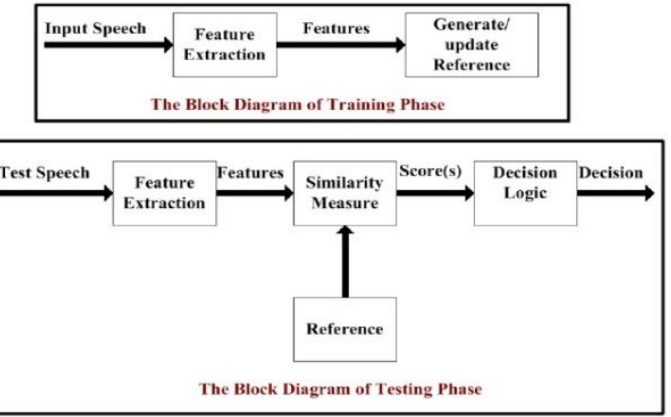

Gambar 2. Blok diagram pengenalan suara fase latihan dan fase pencobaan[6].

Pada fase pencobaan atau pengenalan, dengan berbekal data referensi pada perangkat, sinyal suara dimasukan lagi kedalam sistem ekstraksi fitur lalu sinyal suara akan di bandingkan dengan data referensi, kemudian diterjemahkan sebagai data keluaran. Data keluaran dapat berupa tulisan ataupun perintah.

Pada Gambar 2. dapat kita lihat adanya feature extraction atau ekstrasi fitur. Pada ekstraksi fitur inilah terdapat banyak metode yang dikembangkan untuk membuat sistem pengenalan suara. Ekstraksi fitur merupakan bagian utama pada sistem pengenalan suara. Hal ini dapat dianggap sebagai jantung dari sistem[5]. Terdapat 4 ekstraksi fitur yang terkenal pada pengenalan suara yaitu Linear Predictive Coding, Mel-Frequency Cepstrum, RASTA Filtering, Probabilistic Linear Discriminate Analysis. Pada modeling sistem atau pengukuran kesamaan untuk membandingkan pola dari suara masukan dengan referensi biasanya digunakan Hidden Markov Model walaupun masih ada banyak model lain yang bisa digunakan.

\section{Voice Recognition Module V3}

Sistem pengenalan suara pada Studi ini dibantu menggunakan modul voice recognition versi 3.1 yang diciptakan oleh Elechouse, sebuah perusahaan yang menciptkan modul-modul elektrik. Elechouse Voice Recognition V3 (VR3) merupakan speaker-dependent modul berbasis chip serial dengan memory flash winbond W25Q16DV. Modul ini mendukung sampai 80 perintah suara tetapi hanya memilki 7 perintah suara yang dapat bekerja dalam satu waktu. Perintah suara dapat dikelompokkan menjadi grup-grup yang berisi maksimal 7 perintah suara. Terdapat dua acara dalam mengoperasikan modul ini yaitu port serial dan general input pins. Dan juga memiliki general output pins yang dapat diatur untuk menciptakan beberama macam gelombang yang sesuai dengan perintah suara yang terekognisi. Modul ini memiliki fitur Arduino library, usercontrol General Pin Output, dan lebar kata yang dapat dilatih sebanyak $1500 \mathrm{~ms}$.

Tabel 1.

Parameter VR3 Module

\begin{tabular}{ll}
\hline \hline & Parameter \\
\hline Voltage & $4.5-5.5$ Volt \\
Current & $<40 \mathrm{~mA}$ \\
Digital Interface & $5 V T T L$ for UART interface and \\
& GPIO \\
Analog Interface & $3.5 \mathrm{~mm}$ mono-channel microphone \\
& connector \\
Size & $31 \mathrm{~mm}$ X 50mm \\
Recognition Accuracy & $99 \%$ (under ideal environment) \\
\hline \hline
\end{tabular}

Bentuk fisik dari voice recognition module v3 (VR3) ini seperti pada Gambar 3.

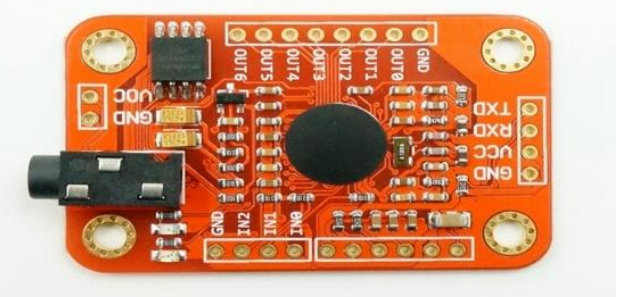

Gambar 3. Bentuk fisik Voice Recognition Module V3.

\section{STM32F4 Discovery}

Papan tunggal STM32F4 Discovery adalah mikrokontroller menggunakan chip STM32F407VG yang merupakan mikrokontroller yang high performance dengan ARM Cortex-M4 32-bit yang dapat beroperasi hingga frekuensi $168 \mathrm{MHz}$. Papan tunggal ini dilengkapi dengan digital accelerometer, digital microphone, audio DAC yang terintegrasi dengan claas D speaker driver, USB OTG micro- 
AB connector. Papan tunggal ini sangat cocok untuk aplikasi yang menggunakan audio. Salah satu fitur yang digunakan pada Studi ini adalah pin UART. UART (Universal Asynchronous Receiver Transmitter) merupakan salah satu bentuk komunikasi serial yang terdapat pada papan tunggal STM32F4 Discovery. Tugas utama dari UART adalah mengirim dan menerima data serial, konfigurasi pin dari UART hanya pin $\mathrm{Rx}$ dan pin Tx. Pin $\mathrm{Rx}$ merupakan pin receiver yaitu yang menerima data, dan pin $\mathrm{Tx}$ merupakan pin transmitter yaitu yang mengirim data. Papan tunggal STM32F4 Discovery mempunyai 2 pin UART yaitu UART 4 dan UART 5, dan memilki 4 pin USART yang bisa diatur untuk menjadi pin UART.

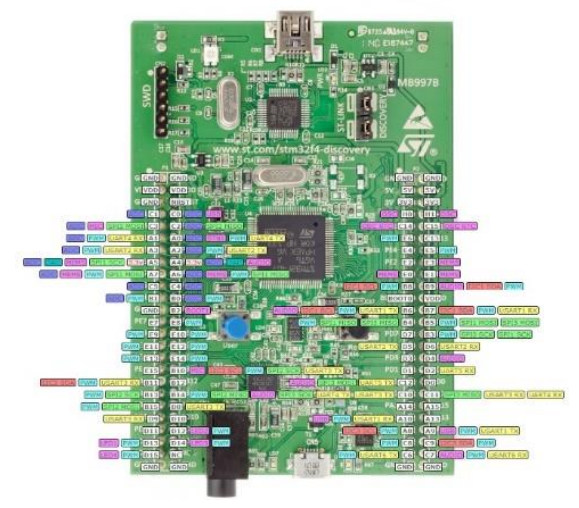

Gambar 4. Pinout STM32F4 Discovery[7].

\section{E. Diagram Blok Sistem Antarmuka}

Dalam Studi ini, sistem yang dibuat adalah antarmuka untuk purwarupa Mesin Cetak Huruf Braille ITS menggunakan dua fitur yaitu pengenalan suara dan juga tombol dengan keluaran suara dari buzzer yang diproses menggunakan papan tunggal STM32F4 Discovery.

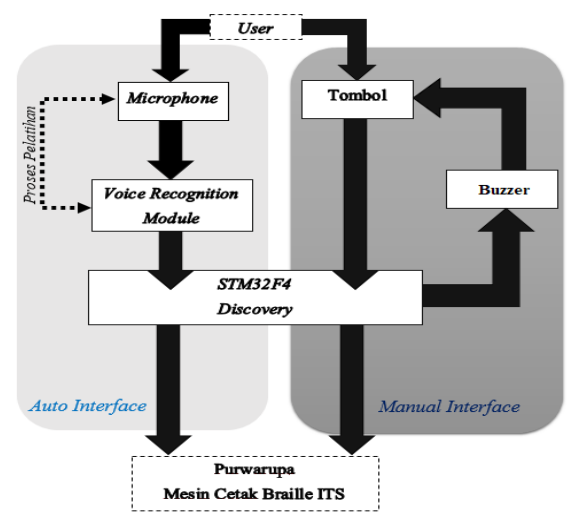

Gambar 5. Diagram blok perangkat sistem antarmuka.

Pada Gambar 5 dapat dilihat diagram blok dari keseluruhan sistem dari antarmuka ini. Dapat dilihat dari diagram blok bahwa sistem antarmuka untuk mengendalikan purwarupa Mesin Cetak Huruf Braille ITS ini terbagi menjadi dua sistem yaitu sistem Auto Interface dan Manual Interface yang mana pada sistem Auto menggunakan kontrol dengan perintah pengelan suara otomatis sedangkan pada sistem interface yang Manual menggunakan tombol yang memberi keluaran berupa suara sebelum digunakan untuk mengontrol purwarpa Mesin Cetak Huruf Braille ITS. Dari kedua sistem antarmuka ini jika digabungkan akan sangat membantu para penyandang tunanetra untuk mengoperasikan Mesin Cetak Huruf Braille ITS.

\section{F. Perancangan Antarmuka Otomatis}

Pada perancangan sistem antarmuka otomatis, digunakan komponen berupa Elechouse Voice Recognition Module V3 sebagai modul pengenalan suara nya, sebuah electret condenser microphone sebagai sensor suara, dan FTDI Serial to USB yang digunakan untuk memantau dan mengambil serta memindahkan data secara serial dari modul pengenalan suara menuju papan tunggal STM32F4 Discovery untuk selanjutnya diproses agar dapat menghasilkan keluaran berupa data 2 bit yang akan dikirim ke board pada purwarupa Mesin Cetak Huruf Braille ITS.

Tahap pertama merupakan pelatihan perintah suara. Pada modul Elechouse Voice Recognition 3 Module harus dilakukan proses pelatihan awal agar modul dapat mengenali suara yang nantinya akan dijadikan command dalam mikrokontroller. Proses pelatihan modul ini dapat dilakukan dengan dua cara yaitu menggunakan library dan sample program dari Arduino atau bisa juga dengan cara komunikasi serial menggunakan serial terminal dengan bantuan FTDI Serial to USB. Pada sistem Auto Interface ini digunakan 4 perintah suara yaitu kata-kata "Test Print", "Satu", "Dua", "Tiga" dengan menggunakan admin suara pria dan wanita. Karena 4 perintah suara dengan dua kategori yaitu pria dan wanita bertotalkan 8 perintah suara yang harus dilatih sedangkan modul Voice Recognition V3 hanya dapat menjalankan 7 perintah dalam waktu yang sama maka untuk masing-masing kategori jenis kelamin nantinya akan diuji satu per satu. Untuk pria diunggah dengan index 0123 dan untuk wanita dengan index 10111213.

Tabel 2.

Daftar kata yang dilatih

\begin{tabular}{ccc}
\hline \hline Kategori & Index & Kata yang dilatih \\
\hline Admin Pria & Sigtrain 0 & Test Print \\
& Sigtrain 1 & Satu \\
& Sigtrain 2 & Dua \\
& Sigtrain 3 & Tiga \\
& Sigtrain 10 & Test Print \\
Admin Wanita & Sigtrain 11 & Satu \\
& Sigtrain 12 & Dua \\
& Sigtrain 13 & Tiga \\
\hline \hline
\end{tabular}

Setelah proses pelatihan kata dilakukan maka proses selanjutnya adalah mengunggah index-index kata tadi kedalam modul. Untuk index yang sudah terlatih (Trained) tetapi tidak diunggah kedalam modul akan tetap tersimpan didalam modul tetapi tidak bisa diaktifkan karena keterbatasan modul. Setelah index-index yang diinginkan diunggah kedalam recognizer, baru pengenalan suara dapat dicoba.

Tahap kedua adalah mengetahui data serial yang dikirim oleh modul Voice Recognition Module V3 saat modul tersebut merekognisi suatu suara yang cocok dengan index, karena modul ini terintegrasi dengan Arduino sedangkan dalam Studi ini mikrokontroller yang digunakan adalah STM32F4 Discovery. Maka proses pengambilan data serial ini menggunakan FTDI Serial to USB dan dengan bantuan aplikasi serial monitor bernama hterm. Untuk membuat modul berada pada posisi stand by dan siap untuk merekognisi suara, masing-masing index yang dibutuhkan harus diunggah terlebih dahulu. Untuk menggunggah, modul harus menerima data serial hex dengan format $|\mathrm{AA}| 3+\mathrm{n} \mid 30$ | R0 | .. $|\mathrm{Rn}| \mathrm{OA} \mid$ dengan $\mathrm{N}$ merupakan index dari perintah yang ingin diunggah. Pengiriman data hex ini dilakukan oleh FTDI Serial to USB pada hterm. LED pada modul yang tadinya menyala akan menjadi blink ini menandakan modul sudah diunggah oleh index-index perintah dan recognizer pada modul siap merekognisi. Setelah melakukan rekognisi suara dapat dilihat bahwa hasil rekognisi suara modul adalah pengiriman data hexadecimal setiap kali salah satu index terekognisi. Dapat dilihat dari hasil pada Tabel 3. 
Tabel 3.

Data Hex yang Dikirim Modul Berdasarkan Pengenalan suara Admin Pria

\begin{tabular}{cc}
\hline \hline $\begin{array}{c}\text { Kata yang } \\
\text { dikenali }\end{array}$ & Data yang dikirim modul (Hex) \\
\hline "Test & $\mathrm{AA}|11| 0 \mathrm{D}|\mathrm{FF}| 00|00| 0 \mathrm{~A}|74| 65|73| 74|50| 72|69| 6 \mathrm{E}|74| 4 \mathrm{D} \mid 0 \mathrm{~A}$ \\
$\begin{array}{c}\text { Print" } \\
\text { "Satu" }\end{array}$ & $\mathrm{AA}|0 \mathrm{C}| 0 \mathrm{D}|00| \mathrm{FF}|01| 01|05| 73|61| 74|75| 4 \mathrm{D} \mid 0 \mathrm{~A}$ \\
"Dua" & $\mathrm{AA}|0 \mathrm{~B}| 0 \mathrm{D}|00| \mathrm{FF}|02| 00|04| 64|75| 61|4 \mathrm{D}| 0 \mathrm{~A}$ \\
"Tiga" & $\mathrm{AA}|0 \mathrm{C}| 0 \mathrm{D}|00| \mathrm{FF}|03| 01|05| 74|69| 67|61| 4 \mathrm{D} \mid 0 \mathrm{~A}$ \\
\hline \hline
\end{tabular}

Di bawah dapat dilihat diagram alir dari keseluruhan sistem perangkat lunak yang terjadi antara Voice Recognition Module V3 dan STM32F4 Discovery pada Gambar 6. (a), Gambar 6. (b), dan Gambar 6. (c). Dapat dilihat pada Gambar 6. (a) dijelaskan mengenai komunikasi antara Voice Recognition Module V3 yaitu proses inisiasi modul untuk membuat modul pada posisi standby dengan mengirimkan data Hexadecimal "Load Recognizer" dengan data $\mid$ AA $\mid 3+n$ | $30|\mathrm{R} 0| \ldots|\mathrm{Rn}|$ 0A|. Jika pada posisi standby modul mengenali perintah suara, maka modul akan mengirimkan data hexadecimal dari perintah suara yang dikenali yang akan disimpan pada buffer.

Pada Gambar 6. (b) dijelaskan mengenai proses pembandingan input data yang disimpan pada buffer dengan buffer database yang sudah ada pada STM32F4. Proses pembandingan dilakukan per satu bit nya. Saat ada bit yang sama penghitung nya bertambah terus sampai ke input bit terakhir.

Pada Gambar 6. (c) dijelaskan proses komunikasi perangkat antarmuka ke pada purwarupa Mesin Cetak Huruf Braille ITS. setelah proses pembandingan input dengan database dan penghitung setiap perintah suara terakumulasi lalu dibandingkan penghitung mana yang memiliki jumlah paling besar (jumlah penghitung = jumlah bit yang sama dengan database). Output yang diberikan oleh papan tunggal STM32F4-Discovery nantinya akan dikoneksikan menjadi input pada papan tunggal yang ada pada purwarupa Mesin Cetak Huruf Braille ITS. Komunikasi antara perangkat antarmuka dengan purwarupa Mesin Cetak menggunakan 2bit data yang sudah dikonfigurasikan pada purwarupa itu sendiri.

Tabel 4.

Konfigurasi Perintah dari STM32F4 ke purwarupa

\begin{tabular}{lll}
\hline \hline Perintah Suara & Bit yang dikirimkan & Perintah pada purwarupa \\
\hline- & 11 & Standby \\
"Test Print" & 11 & Standby \\
"Satu" & 00 & Test Print 1 \\
"Dua" & 01 & Test Print 2 \\
"Tiga" & 10 & Test Print 3 \\
\hline \hline
\end{tabular}

Pada Gambar 7, bit yang selalu masuk untuk membuat purwarupa ini berada pada keadaan standby adalah bit 11 . Jika ada perintah yang mengirimkan bit " $00 "$, " 01 ", " 10 " harus langsung dikembalikan ke bit 11 kembali untuk posisi standby sehingga perintah "Satu", "Dua", dan "Tiga" merupakan perintah berupa trigger saja.

\section{G. Perancangan Antarmuka Manual}

Pada perancangan manual yang ditunjukkan pada Gambar8 digunakan 3 buah push button, buzzer dan papan tunggal STM32F4 Discovery sebagai mikrokontroller nya, buzzer digunakan untuk mengeluarkan suara saat tombol ditekan. Push button dikoneksikan dengan pin input pada STM32F4 dan pin output dikoneksikan pada buzzer. Karena terdapat 3 perintah yang harus dikomunikasikan terhadap purwarupa Mesin Cetak Huruf Braille ITS, maka dibutuhkan 3 buah push button dengan bunyi buzzer yang masing-masing berbeda untuk membedakan masing-masing tombol dengan suara.
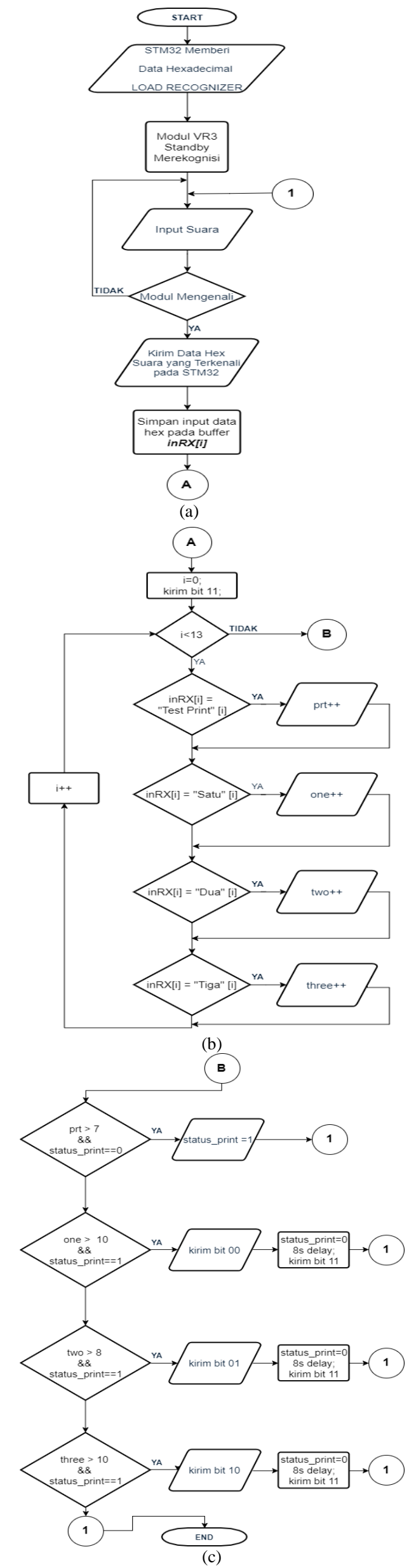

Gambar 6. Flowchart auto interface (a) (b) (c). 
Perancangan ini menggunakan counter pada push button saat, push button ditekan kurang dari 3 detik maka output dari push button tersebut adalah buzzer, sedangkan saat push button ditekan lebih dari 3 detik maka output dari push button adalah komunikasi pada purwarupa. Bentuk komunikasi ketiga push button ini sama seperti pada perancangan antarmuka otomatis.

\section{H. Perancangan Perangkat Elektrik}

Pin yang digunakan adalah PA3 sebagai Tx dan PA2 sebagai Rx, PD13 dan PD15 adalah D0 dan D1 untuk dikonesikan pada Purwarupa Mesin Cetak Huruf Braille ITS, PD13 dan PD15 juga merupakan pin LED papan tunggal STM32F4 Discovery, sehingga dapat dipantau keluarannya melalui LED. PD12 dikoneksikan dengan buzzer dan juga merupakan pin LED pada papan tunggal STM32F4 Discovery. PD0, PA15, PA13 adalah pin push button.

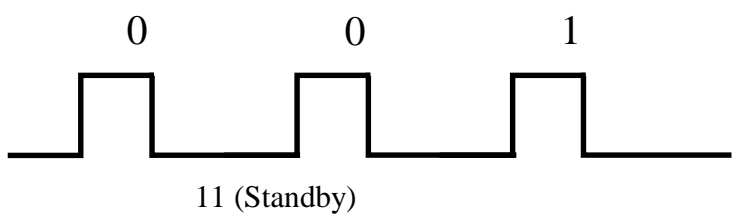

Gambar 7. Proses komunikasi pada Purwarupa.

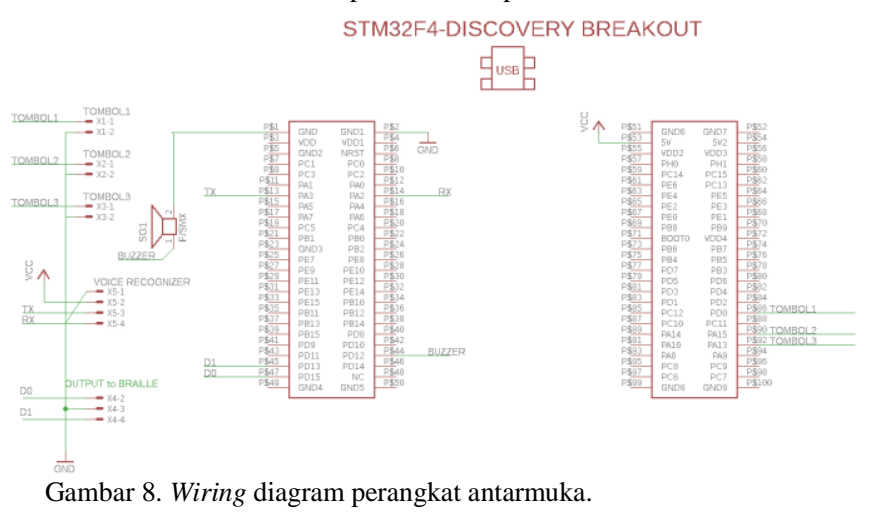

III. HASIL DAN DISKUSI

Pengujian dilakukan dengan pengujian pengenalan suara pada antarmuka otomatis dan komunikasi antara perangkat antarmuka dengan purwarupa Mesin Cetak Huruf Braille ITS.

\section{A. Pengujian Pengenalan Suara}

Pada tahap pengujian pengenalan suara oleh Voice Recognition V3 Module by Elechouse dilakukan menggunakan Arduino untuk menguji keberhasilan rekognisi suara pada modul. Pengujian dilakukan dengan 3 kali percobaan yaitu, 8 orang pria diuji dengan database admin pria, 8 orang wanita diuji dengan referensi database admin wanita. Lalu 3 orang pria dan wanita diuji dengan referensi database nya masing-masing. Pria dan wanita yang menjadi penguji berumur 20-22 tahun.

Dari ketiga cara uji coba tersebut (Pria - Admin, Wanita Admin, Pria \& Wanita - Sendiri) didapat sebuah hasil dimana rata-rata persentase tingkat keberhasilan dari sistem Auto Interface yang menggunakan modul Voice Recognition V3 Module by Elechouse adalah seperti yang ditampilkan pada Tabel 5.
Tabel 5.

Rata-Rata Persentase Keberhasilan

\begin{tabular}{cc}
\hline \hline Uji Coba & Persentase \\
\hline Pria-Admin & $55,63 \%$ \\
Wanita-Admin & $66,25 \%$ \\
Referensi Orang Lain & $60,94 \%$ \\
Admin-Admin & $77,92 \%$ \\
\hline
\end{tabular}

Setiap ujicoba dilakukan pengujian per perintah suara dan didapati bahwa terdapat perintah suara yang lebih mudah dikenali dan terdapat perintah suara yang susah dikenali dapat dilihat datanya pada Gambar 9 (a), Gambar 9 (b).

\section{Keberhasilan Rekognisi (Pria)}

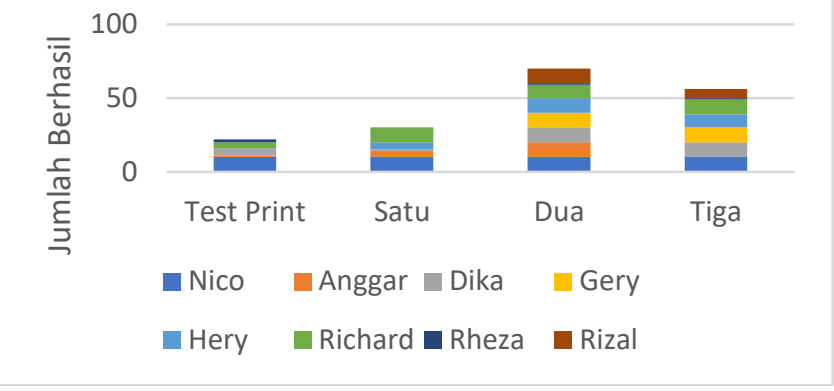

(a)

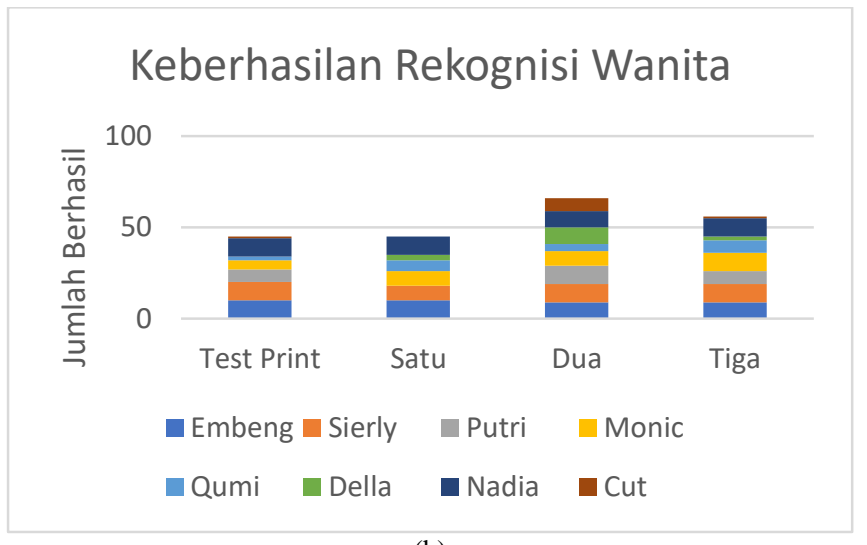

(b)

Gambar 8. (a) Diagram batang keberhasilan rekognisi perintah suara pada pria (b) Diagram batang keberhasilan rekognisi perintah suara pada wanita.

\section{Perbandingan Persentase Keberhasilan Rekognisi}

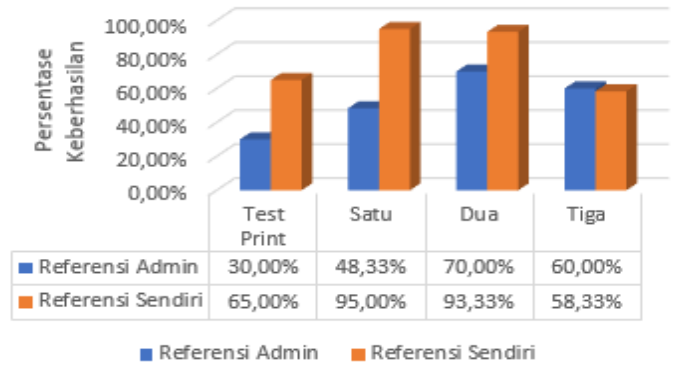

Gambar 10. Diagram batang perbandingan persentase keberhasilan rekognisi.

Setelah melihat data pada Gambar 10 dapat disimpulkan bahwa hasil dari pengujian menggunakan referensi suara sendiri hasilnya akan jauh lebih bagus, walaupun terdapat sedikit penurunan pada kata "Tiga" dari $60 \%$ menjadi $58,33 \%$. 
Pada pengujian menggunakan modul Voice Recognition V3 Module by Elechouse didapatkan bahwa persentase keberhasilan menggunakan referensi suara sendiri memiliki jumlah yang lebih besar dibanding pengujian menggunakan referensi suara orang lain. Namun dalam pengujian menggunakan referensi suara sendiri juga memiliki sedikit error, hal ini dikarenakan oleh beberapa faktor lain yaitu intonasi dan volume suara serta jarak penguji terhadap mikrofon. Hal ini terjadi juga dalam penelitian "Testing of Other Languages Usage in Addition to the Default Languages for the Easy Voice Recognition Module" oleh Rustam Asnawi dan Muhammad Said yang menggunakan modul pengenalan suara Easy VR 3.0 bahwa modul mengenali suara melalui pengenalan perintah suara dan pengenalan dari intonasi suara. Orang yang tahu perintah suara dan tidak mengucapkan perintah suara dengan intonasi yang tepat seperti pada referensi, akan ditolak oleh sistem[8]. Dari hal ini dapat diketahui bahwa intonasi sangat berpengaruh pada beberapa modul pengenalan suara.

B. Pengujian Komunikasi antara Perangkat Antarmuka dengan Purwarupa Mesin Cetak Huruf Braille ITS

Pada purwarupa Mesin Cetak Huruf Braille ITS, terdapat 3 pola test print, pola ini dapat dilihat pada Gambar 10. (a), Gambar 10. (b), Gambar 10. (c). Seperti yang sudah dibahas pada sub-bab Perancangan Antarmuka Otomatis, bahwa dari 4 perintah suara, yang mengirimkan output pada purwarupa hanya 3 dengan output pengiriman bit 00, bit 01, bit 10 .

Pengujian komunikasi pada purwarupa ini dilakukan oleh Pak Tasripan yang suaranya sudah terlebih dahulu dilatih kedalam sistem, hasil uji coba dapat dilihat Gambar 11, Gambar 12, dan Gambar 13.

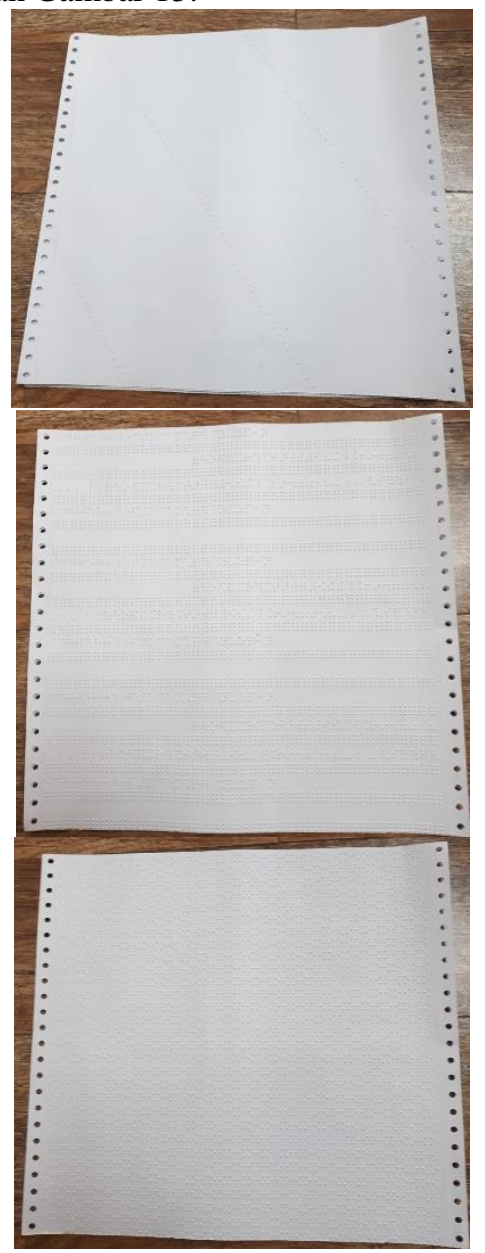

Gambar 10. (a) Pola Test Print Satu (b) Pola Test Print Dua (c) Pola Test Print Tiga.
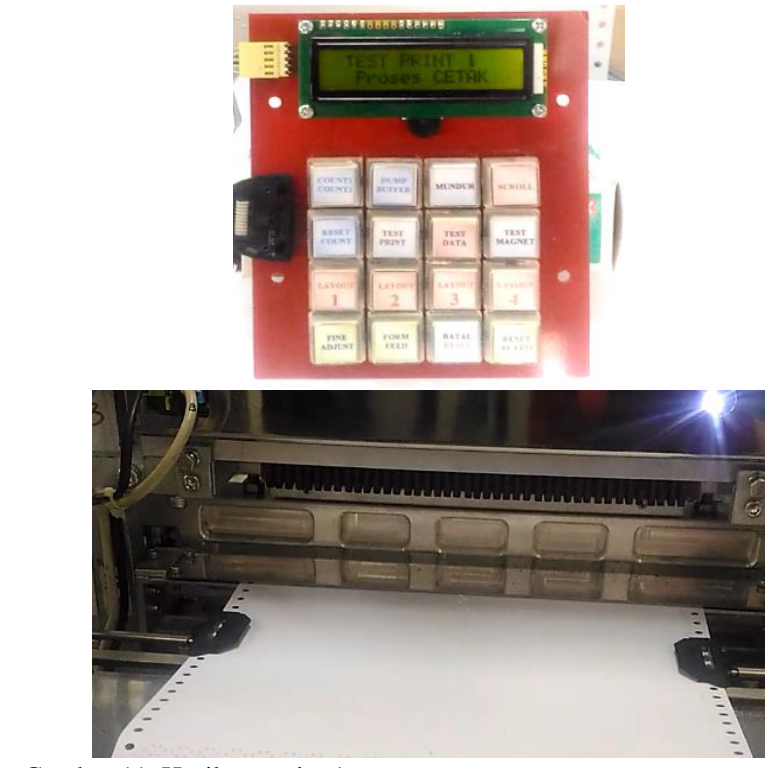

Gambar 11. Hasil test print 1.
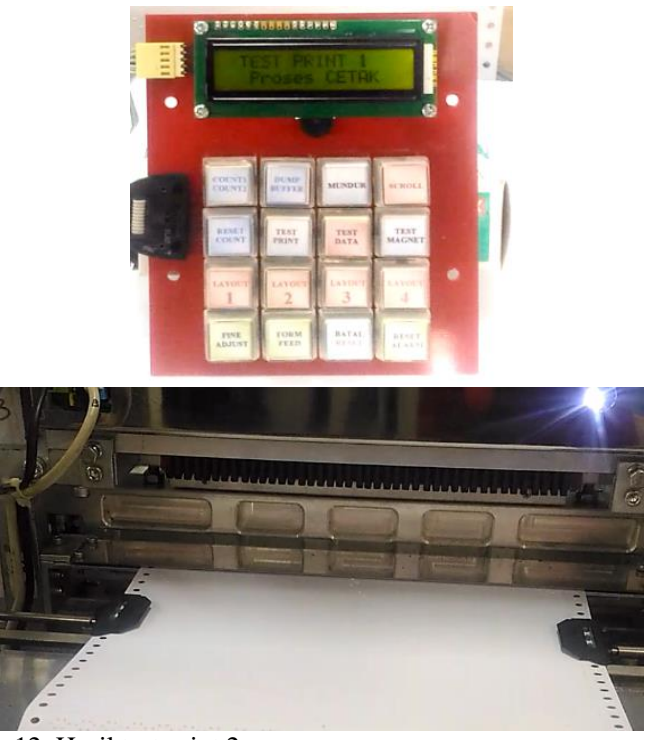

Gambar 12. Hasil test print 2.
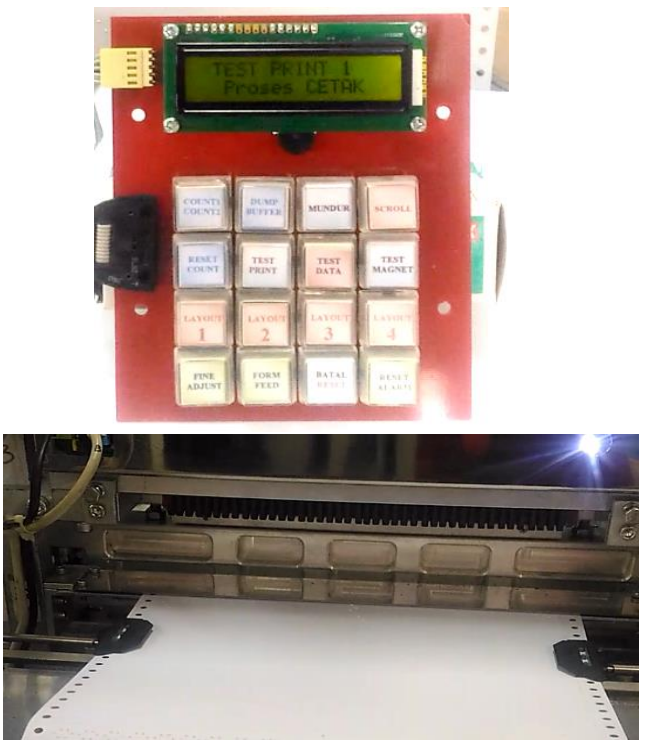

Gambar 13. Hasil test print 3.

Pada hasil pengujian masing-masing perintah suara sudah dapat dilihat bahwa semua perintah suara sudah dapat berkomunikasi dengan baik dengan menjalankan perintahnya dengan benar pada purwarupa yang ditunjukkan pada Gambar 11., Gambar 12., Gambar 13. 


\section{KESIMPULAN}

Sistem interface hardware yang dibuat dengan dua sistem Auto dan Manual Interface mampu berjalan dengan baik dengan keberhasilan $60,94 \%$ dengan referensi suara orang lain dan $77,92 \%$ referensi suara sendiri, namun ada beberapa hal yang mempengaruhi keberhasilan yaitu kondisi ruangan sekitar, semakin ramai kondisi ruangan akan semakin sulit modul mampu dalam mengenali suara. Intonasi dan volume suara, volume suara yang lebih tegas dan keras saat proses pelatihan modul akan lebih mudah dikenali nantinya saat diuji, intonasi juga sangat berpengaruh, dengan user yang sama tetapi mengubah nada intonasi juga sedikit lebih susah dikenali oleh modul, begitupula user yang berbeda tetapi berusaha memiripkan nada atau intonasi dari suara referensinya akan sedikit lebih mudah untuk dikenali. Dan berdasarkan data tingkat keberhasilan dapat dilihat referensi dengan suara sendiri lebih akurat daripada dengan referensi suara orang lain.

\section{DAFTAR PUSTAKA}

[1] Anon ITS Siap Pasarkan Mesin Cetak Braille - ITS News

[2] Zhang Z 2016 Mechanics of Human Voice Production and Control $J$. Acoust. Soc. Am. 140 2614-35

[3] Honda K 2008 Physiological Processes of Speech Production Springer Handbook of Speech Processing (Berlin, Heidelberg: Springer Berlin Heidelberg) pp 7-26

[4] Rubin P and Vatikiotis-Bateson E 1998 Measuring and Modeling Speech Production Animal Acoustic Communication (Berlin, Heidelberg: Springer Berlin Heidelberg) pp 251-90

[5] Narang S and Divya Gupta M 2015 International Journal of Computer Science and Mobile Computing Speech Feature Extraction Techniques: A Review vol 4

[6] Muaidi H, Bin A, Al-Ahmad A, Khdoor T, Alqrainy S and Alkoffash M 2014 Arabic Audio News Retrieval System Using Dependent Speaker Mode, Mel Frequency Cepstral Coefficient and Dynamic Time Warping Techniques Res. J. Appl. Sci. Eng. Technol. 7 5082-97

[7] Anon stm32f4 discovery pinout - Members Albums Category - Virtual Pinball Universe

[8] Asnawi R and Said M 2018 Testing of Other Languages Usage in Addition to The Default Languages for The Easy Voice Recognition Module 2018 International Conference on Electronics Technology (ICET) (IEEE) pp 321-4 